\title{
Rootstock Characteristics of Three Combinations of Theobroma cacao L. Crosses on Different Water Availability
}

\author{
Bayu Setyawan ${ }^{1^{*}}$, Niken Puspitasari ${ }^{1)}$, Agung Wahyu Susilo ${ }^{1)}$, and Indah Anita Sari ${ }^{1)}$ \\ 1)Indonesian Coffee and Cocoa Research Institute, J1. PB Sudirman No. 90, Jember 68118, Indonesia \\ "Corresponding author: bayu.setyawan@iccri.net \\ Received: 28 September 2018 / Accepted: 20 October 2018
}

\begin{abstract}
Climate change is universal phenomena which is importantly anticipated including cocoa plantation. Drought tolerance cocoa seedling is urgently needed to develop cocoa plantation. This paper studied possible drought tolerance of cocoa seedling through crossing between female parent KKM 22 with three male parents BAL 209, KW 641, and KW 614. Progeny test was conducted in green house based on four water availability conditions: $25,50,75$, and $100 \%$. Root condition was recorded as rootstock parameters of three crossings. Result showed that root characteristics varied among crossing samples studied. The longest and hight volume root were recorded from KKM 22 x BAL 209 crossing. Seedling of KKM $22 \times$ BAL 209 crossing tended to have long and wide root, while seedling of KKM $22 \times \mathrm{KW} 641$ crossing tended to have a wide root type and seedling of KKM $22 \times \mathrm{KW} 614$ tended to have a long root type. Based on drought tolerancy, seedling of KKM $22 \times \mathrm{KW} 641$ crossing could be classified as drought tolerance while other two group progenies could be classified as susceptible to drought. To conclude, seedling of KKM 22 x KW 641 can be recommended for cocoa plantation in drought area.
\end{abstract}

Keywords: Drought-tolerant, root characteristic, rootstock, cocoa, stress index

\section{INTRODUCTION}

Climate is a determinant factor of growth and development of crops including cocoa. As climate continues to change, the main factor causing climate change to occur rapidly is the increase in carbon gas production (Solomon et al., 2009). Climate change causes an increase in the surface temperature of the earth or more popular with the events of global warming. Global warming is an event of rising earth temperatures due to long and short waves of sunlight trapped by greenhouse gases. The impact of such events varying as global rainfall changes, climate change and unpredictability, and changes in patterns of pests and diseases in plants (Nelson et al., 2010). Global warming events will have an impact on sites that were originally conceived as land crop production into marginal land, especially in terms of water availability (Baclund et al., 2008). It poses a threat to agricultural production including cocoa resulting in a decrease in productivity and production.

Cocoa production is related to three climate parameters such as rainfall, humidity, temperature, and integration between these parameters. Rainfall is the parameter that most affect the productivity of cocoa, this is because cocoa is very sensitive to drought 
and cocoa planting pattern associated with the distribution of rainfall (Amos \& Thompson, 2015). Cocoa water requirement is important when the seedling phase because the seeds are water shortage will be inhibited growth and can even dry and die (Ayegboyin \& Akinrinde 2016). In the fruit formation phase if there is water shortage then the fruit that is formed not maximal even extreme fruit will fall out (Adjaloo et al., 2012). These conditions constitute a threat to the cultivation of cocoa.

Drought-tolerant cocoa seedlings are needed to overcome drought threats. Rootstock is a very related part of groundwater availability (Jones, 2012), so in order to obtain drought-tolerant cacao plants, rootstocks that have certain rooting characteristics that indicate the ability to survive in dry conditions.

The root characteristics associated with drought include total root length, root density, root diameter, density of root tissue, specific root length, and specific root surface area (Ostonen et al. 2007). Most of the root traits are controlled by many genes, each influenced by the degree of epistasis and interactions that can change depending on environmental conditions. Phenotypic variation of the root trait is influenced by genetic variation and environmental variation in which plants grow. Environmental variations are strongly related to soil and climate conditions (Comas et al.2013). Crosses between parents produce genetic diversity that has the potential to produce cacao plants that have a potentially tolerant rootstock characteristic of drought stress conditions. Currently, data and information on rootstock character and roots of drought-resistant cocoa have not been studied. This paper studied cocoa rooting character associated with tolerance to drought so as to support the assembly of drought tolerant cocoa seedlings.

\section{MATERIALS AND METHODS}

The parents for crossing used in this study were KKM 22, BAL 209, KW 614, and KW 641. The cross design was used a nested method in which female KKM 22 was fertilized by three males (BAL 209, KW 614, and KW 641). Having obtained F1 (first progeny) is then tested on different water availability. The experimental design using randomized factorial design with the first factor were F1 from three crossing between parents and water availability as the second factor by adding $25,50,75$, and $100 \%$ in the soil. This condition is made after the moisture content of the field capacity and permanent wilting point has been determined. Determination of moisture content and permanent wilting point in planting media that will be used is tested at Soil Laboratory of Indonesian Coffee and Cocoa Research Institute, Jember.

The method of adding water in the treatment of drought stress based on research conducted by Prawoto et al. (2003). Water added is done at intervals of five days as a second factor (Table 1). The study starts from early 2017 until the end of September 2017 and is placed in the Greenhouse of Kaliwining

Table 1. Analysis of variance randomized factorial design

\begin{tabular}{|c|c|c|c|c|}
\hline $\begin{array}{l}\text { Source of } \\
\text { variation }\end{array}$ & $\mathrm{df}$ & SS & MS & $\mathrm{E}(\mathrm{MS})$ \\
\hline $\begin{array}{l}\text { Hybrids } \\
\text { Water Availability } \\
\text { Hybrids*Water } \\
\text { Availability }\end{array}$ & $\begin{array}{c}a \\
b \\
(a-1)(b-\end{array}$ & $\begin{array}{l}\mathrm{SS}_{\text {hybrids }} \\
\mathrm{SS}_{\text {water availability }} \\
\mathrm{S}_{\text {hybrids*water availability }}\end{array}$ & $\begin{array}{c}\mathrm{SS}_{\text {hybrids }} / \mathrm{a} \\
\mathrm{SS}_{\text {water availability }} / \mathrm{b} \\
\mathrm{SS}_{\text {hybrids*water availability }} / \\
(\mathrm{a}-1)(\mathrm{b}-1)\end{array}$ & $\begin{array}{l}\mathrm{s}_{\text {error }}{ }^{2}+\mathrm{n} \cdot \mathrm{s}_{\text {hybrids*water availability }}+\mathrm{n} \cdot \mathrm{b} \cdot \mathrm{s}_{\text {hybrids }} \\
{ }_{\text {error }}^{2}+\mathrm{n} \cdot \mathrm{s}^{2}{ }_{\text {hybrids*water availability }}+\mathrm{n} \cdot \mathrm{a} \cdot \mathrm{s}^{2}{ }_{\text {water availability }} \\
\mathrm{s}_{\text {error }}^{2}+\mathrm{n} \cdot \mathrm{s}^{2}{ }_{\text {hybrids*water availability }}\end{array}$ \\
\hline Error & $\mathrm{N}-\mathrm{ab}$ & $\mathrm{SS}_{\text {error }}$ & $\mathrm{SS}_{\text {error }} /(\mathrm{N}-1)$ & $\mathrm{S}_{\text {error }}{ }^{2}$ \\
\hline Total & N-1 & $\mathrm{SS}_{\text {total }}$ & & \\
\hline
\end{tabular}


Coffee and Cocoa Research Institute. The tools used are digital caliper, digital camera, and imageJ software. The necessary research materials include crossing material and insepticol soil.

Observations of growth variables associated with drought include fresh and dry weight of plant, stem diameter, root length, root volume, root area, root/shoot ratio, root proline, and drought sensitivity is measured using the formula (Shirani Rad \& Abbasian, 2011):

SSI ( stress susceptibility index $)=$

$$
\frac{1-\left(\frac{Y S}{Y p}\right)}{1-\left(\frac{\bar{Y} S}{\bar{Y} p}\right)}
$$

Where:

(Y) $=$ the mean value of the variables on the genotype with drought stress,

$(\mathrm{Yp})=$ the mean value of the variables at one genotype in the optimum environment,

(Ys) $=$ the mean value of the variables in all clones with drought stress,

$(\bar{Y} \mathrm{p})=$ the mean value of the variables on all genotypes in the optimum environment, and

(s) $\quad=$ the mean value of the variables in all genotypes in a tense environment

The data collected after fulfilling the assumptions of the subsequent analysis were analyzed variance at $95 \%$ confidence level. If there is a difference between treatments there is continued test using Duncan's multiple range test (DMRT) with 95\% confidence level for hybrids treatment and a trend pattern test for the watering treatment.

Table 1. Used as a reference in the predicted variance affecting the observed variables whether the phenotypic variance $\left(\mathrm{s}_{\mathrm{f}}^{2}=\mathrm{s}_{\mathrm{g}}^{2}\right.$ $+\mathrm{s}_{\mathrm{e}}^{2}$ ) is more influenced by the genetic factor $\left(\mathrm{s}_{\mathrm{g}}^{2}\right)$ expected from $\mathrm{s}_{\text {hybrids }}{ }^{2}$, the environmental factor $\left(\mathrm{s}_{\mathrm{e}}^{2}\right)$ expected from $\mathrm{s}_{\text {water availability }}{ }^{2}+$ $\mathrm{s}_{\text {error }}{ }^{2}$. Ratio $\left(\mathrm{s}_{\mathrm{g}}{ }^{2} / \mathrm{s}_{\mathrm{e}}{ }^{2}\right)$ of the expected variance is interpreted in heritability broad sense $\left(\mathrm{H}^{2}\right)$, the greater the value of $\mathrm{H}^{2}$ the character is more affected by the genetic variation than the environment (Visscher et al., 2008).

\section{RESULTS AND DISCUSSION}

\section{Rootstock Morphological Characters}

The superiority of a seedling is determined by the morphology of some rootstock characters supporting the growth of the scion. Among these characters are the stem diameter, root area, and root volume. Seedlings from KKM 22 x BAL 209 have superior rootstock characteristics because they have the highest value on stem diameter, root area, and root volume but not significantly different with seedlings from KKM $22 \times \mathrm{KW} 641$ (Table 2.). Deep and abundant roots characterize plants more tolerant to dry conditions than plants with shallow roots (Paez-garcia et al., 2015).

Shoot of the three seedlings of the crossing shows a high uniformity seen from the same performance, but at the root of the seedlings of KKM $22 \times$ BAL 209 and KKM $22 \times$ KW 641 has a heavier root than KKM $22 \times$ KW 614 so that ratio or comparison between root and shoot higher (Table 2), a high root-shoot ratio produced stronger seedlings (Beets et al., 2007).

The three offspring of the crossing combination show a linear pattern on the root length and root area (Figure 1). The growth and development of roots depends

Table 2. Rootstock characters of three cocoa seedling populations

\begin{tabular}{|c|c|c|c|c|c|c|c|}
\hline Hybrids & $\begin{array}{c}\text { Stem } \\
\text { diameter }(\mathrm{mm})\end{array}$ & $\begin{array}{l}\text { Root dry } \\
\text { weight (g) }\end{array}$ & $\begin{array}{l}\text { Shoot dry } \\
\text { weight (g) }\end{array}$ & $\begin{array}{c}\text { Root } \\
\text { lenght }(\mathrm{cm})\end{array}$ & $\begin{array}{c}\text { Root } \\
\text { area }\left(\mathrm{cm}^{2}\right)\end{array}$ & $\begin{array}{c}\text { Root } \\
\text { volume }\left(\mathrm{cm}^{3}\right)\end{array}$ & $\begin{array}{c}\text { Root }- \text { shoot } \\
\text { ratio }\end{array}$ \\
\hline KKM $22 \times$ BAL 209 & $4.34^{\mathrm{a}}$ & $1.67^{\mathrm{a}}$ & $3.64^{\mathrm{a}}$ & $24.84^{b}$ & $107.78^{a}$ & $6.72^{a}$ & $0.46^{\mathrm{ab}}$ \\
\hline KKM $22 \times$ KW 641 & $4.10^{\mathrm{a}}$ & $1.52^{\mathrm{a}}$ & $3.14^{\mathrm{a}}$ & $24.24^{b}$ & $87.68^{b}$ & $5.68^{a b}$ & $0.64^{\mathrm{a}}$ \\
\hline KKM $22 \times$ KW 614 & $3.46^{\mathrm{b}}$ & $1.04^{b}$ & $3.20^{\mathrm{a}}$ & $31.26^{\mathrm{a}}$ & $94.74^{a b}$ & $4.98^{c}$ & $0.35^{\mathrm{b}}$ \\
\hline
\end{tabular}
Duncan test at $95 \%$ confidence level. 
on the availability of water at a particular location. In addition to the environment, the genetics of planting materials used have different responses to the availability of water. Seedlings from KKM $22 \times \mathrm{KW} 641$ and KKM 22 x BAL 209 have a more declivous pattern on the root length variables, meaning the progenies are not very sensitive to changes in water content in the media or more adaptive to drought stress conditions. Plants categorized as to be adaptive when there is no apparent change between the stress conditions and without stress (Amrhein et al., 2013).

In contrast to root length, the root area of each cross show the same response to water availability. However, the seeds crossed KKM 22 x KW 641 changes in root area are not as sheer as other crosses, meaning that this cross produce progenies that is quite tolerant of changes in water conditions. The condition of water more available then the area of roots that formed by plant more extensive. Root growth is affected by soil fertility and water availability in soil, if enough water is available in soil root growth will be good (Kramer \& Boyer 1995). The root growth plasticity depends on the availability of water in the soil, the more available the water the better root growth (Paez-garcia et al., 2015).

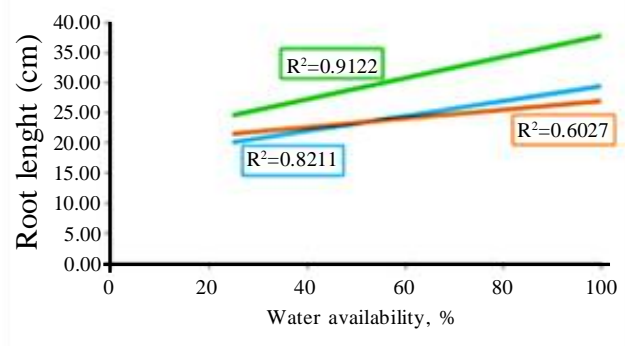

— KKM 22 × BAL 209 KKM $22 \times$ KW 641 KKM 22 × KW 614
Plant root morphology given the most severe drought stress $(25 \%)$ showed that the tap root trait characteristics (root axis) were smaller and tend to be long downward, the relatively few secondary roots formed compared to other water stress treatments (Figure 2.). In contrast to the conditions of sufficient water the plants tend to form secondary roots and other root branches. Long roots in plants allow plants to ensure water availability for plants, while root-shaped hair is a mechanism in expanding its uptake (Vadez, 2014).

The three cross breeds that used indicate seedlings from KKM $22 \times \mathrm{KW} 614$ has an elongated root type, seedlings from KKM 22 x BAL 209 and KKM 22 x KW 641 has an ideal root root root type with polybag size and widespread secondary root spread. Root plant architecture that has deep roots, many root fibers and high root densities is a criterion of plants that can be used to overcome drought (Siddique et al., 2015).

Broad sense heritability of rootstocks character of cocoa shows low-moderate values (Table 3). Broad sense heritability is used to see the extent of genetic factor in determining the phenotypic character, the greater its value the contribution of the genetic factor is increasingly involved (Ajayi et al., 2014). The phenotypic traits of stem

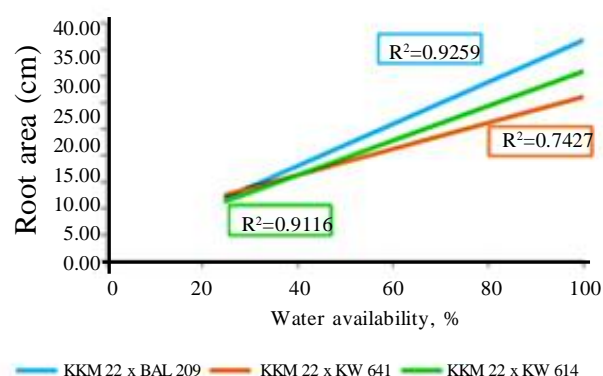

Figure 1. Relationship pattern between water availability and root lenght and root area of three cocoa seedling populations 
Table 3. Broad sense heritabilty of rootstock traits

\begin{tabular}{lrrrr}
\hline Traits & \multicolumn{1}{c}{$\mathrm{s}_{\mathrm{g}}^{2}$} & $\mathrm{~s}_{\mathrm{e}}{ }^{2}$ & $\mathrm{~s}_{\mathrm{f}}{ }^{2}$ & $\mathrm{H}^{2}$ \\
\hline Stem diameter & 0.17 & 0.42 & 0.59 & 0.29 \\
Root lenght & 13.30 & 38.94 & 52.24 & 0.25 \\
Root area & 46.59 & 2577.09 & 2623.68 & 0.02 \\
Root volume & 0.43 & 13.68 & 14.11 & 0.03 \\
Root dry weight & 0.09 & 0.58 & 0.67 & 0.13 \\
\hline
\end{tabular}
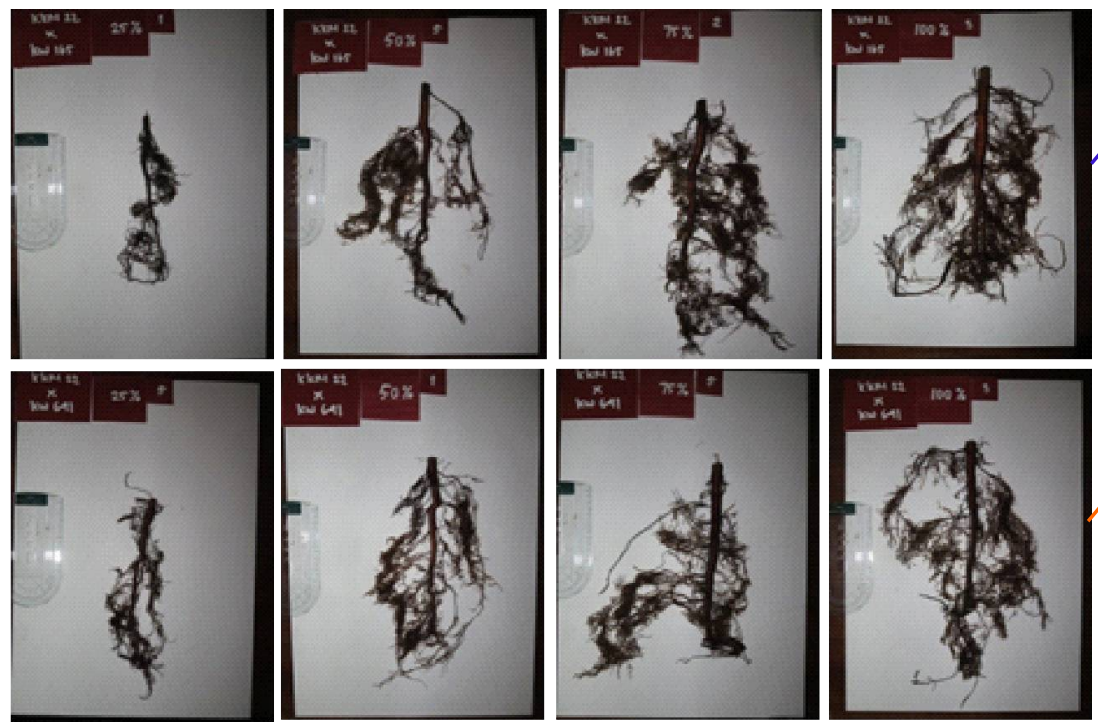

(KKM $22 \times$ KW 641)
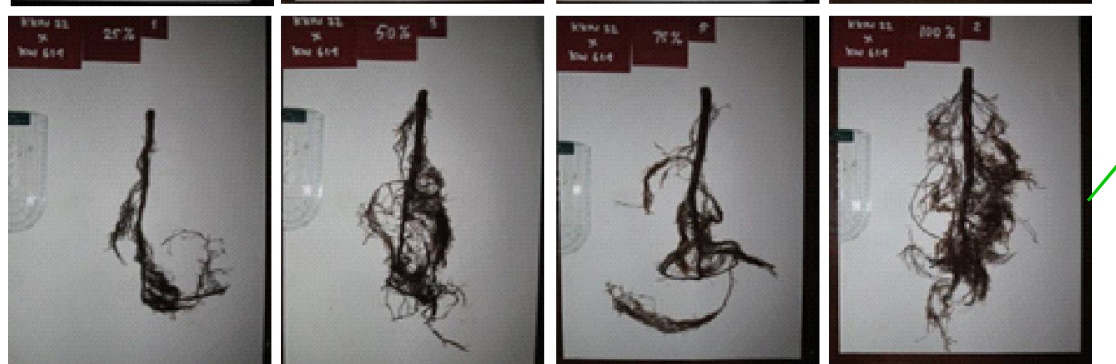

(KKM 22 x KW 614)

Figure 2. Root morphology from three crosses populations at different water availability 25, 50, 75, and $100 \%$ (left-right) $(1: 9$ scale)

diameter and root length were the variables in the study influenced by $1 / 3$ and $1 / 4$ of the genetic factors, while the other observational variables were influenced by only $15 \%$ of the genetic factors. High genetic influences make the selection/use of superior genotypes more targeted because the related traits will be inherited on to generations/ progenies. In selection to improve offspring, variables that have medium heritability value are better used as selection criteria for the next generation (Sudarmadji, 2007).

\section{Rootstock Physiological Character}

Based on the drought stress susceptibility index (Figure 3), only KKM 22 x KW 641 has index below 1, drought susceptibility index indicates the ability of plants to survive in drought stress condition, when compared with KKM 22 x BAL 209 index value above 1 ( $>$ 1) means the plant is very susceptible to drought stress. The index values above 1 plant are susceptible, the susceptibility index below 0.5 is tolerant to stress and 0.5 $<$ the stress index value (s) $<1.0$ means the 
plant has a moderate ability in drought stress (Savitri, 2010).

The three crosses populations show different responses to drought stress based on root proline production (Figure 4.). Plants are said to be tolerant if in the drought conditions are less in proline production (Lum, et al., 2014). The crosses that show the lowest root proline production are KKM 22 $x$ BAL 209 which produces the number of proline and KKM $22 \times \mathrm{KW} 641$ produce of KKM $22 \times$ KW 614. Proline production is closely related to drought stress, proline production is increasingly increased is a response from the plant in an effort to withstand in drought condition (Medeiros et al., 2012).

In Indonesia, the development of superior varieties of cocoa has been started since 1911 until now. Some of the superior cocoa varieties that have been released by the Indonesian government have high production, pest and diseases resistant such as cacao pod borer and vascular streak dieback (VSD) (Pusat Penelitian Kopi dan Kakao Indonesia, 2015). Cultivation of cocoa in drought conditions in Indonesia such as Nusa Tenggara Timur and other dry areas require improved varieties that are tolerant to dry conditions, there are currently no suitable varieties under that conditions.

Morphological and physiological characteristics of the study results show that the cross between KKM $22 \times$ KW 641 has an ideal rootstock morphology characteristic based on its rooting morphology. Besides being supported by root morphology, this crossing population has low drought susceptibility and low proline production during drought stress. That rootstock characters can be used as a reference in breeding for drought tolerant rootstock to obtain cacao plant varieties suitable for cultivation of dryland cocoa.

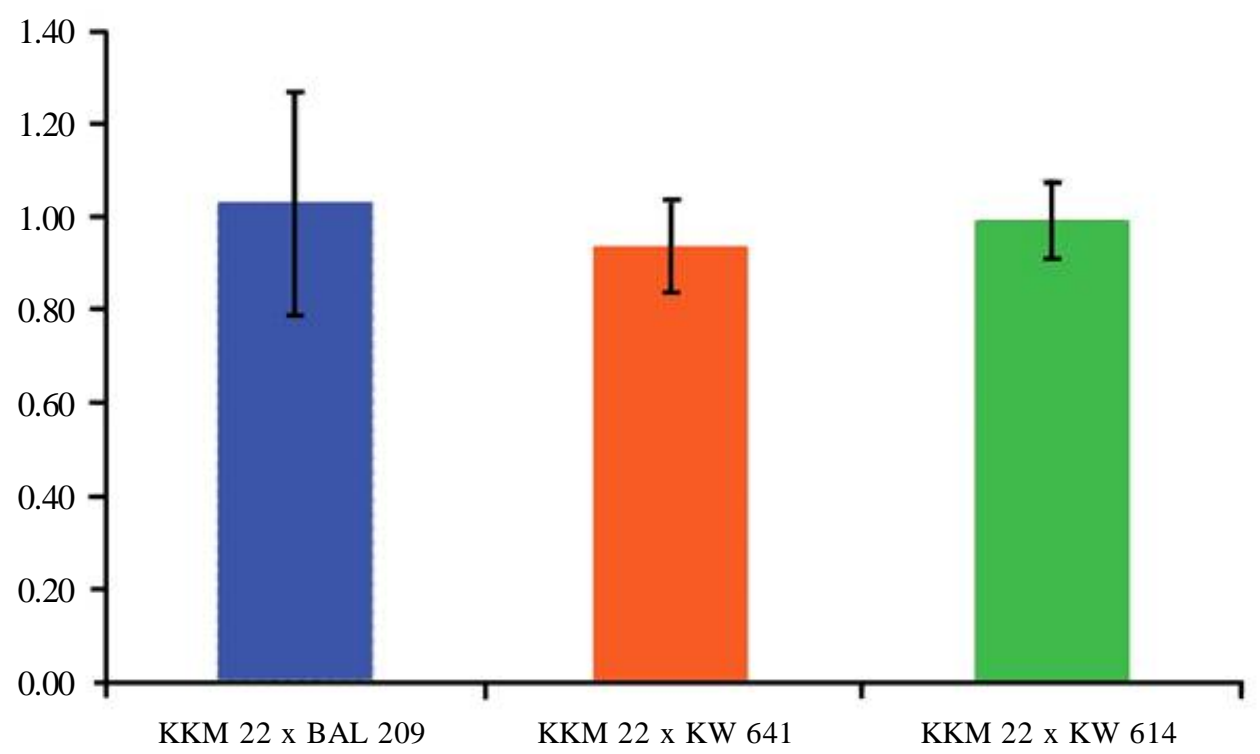

Figure 3. Drought susceptibility index of three cocoa seedling populations 


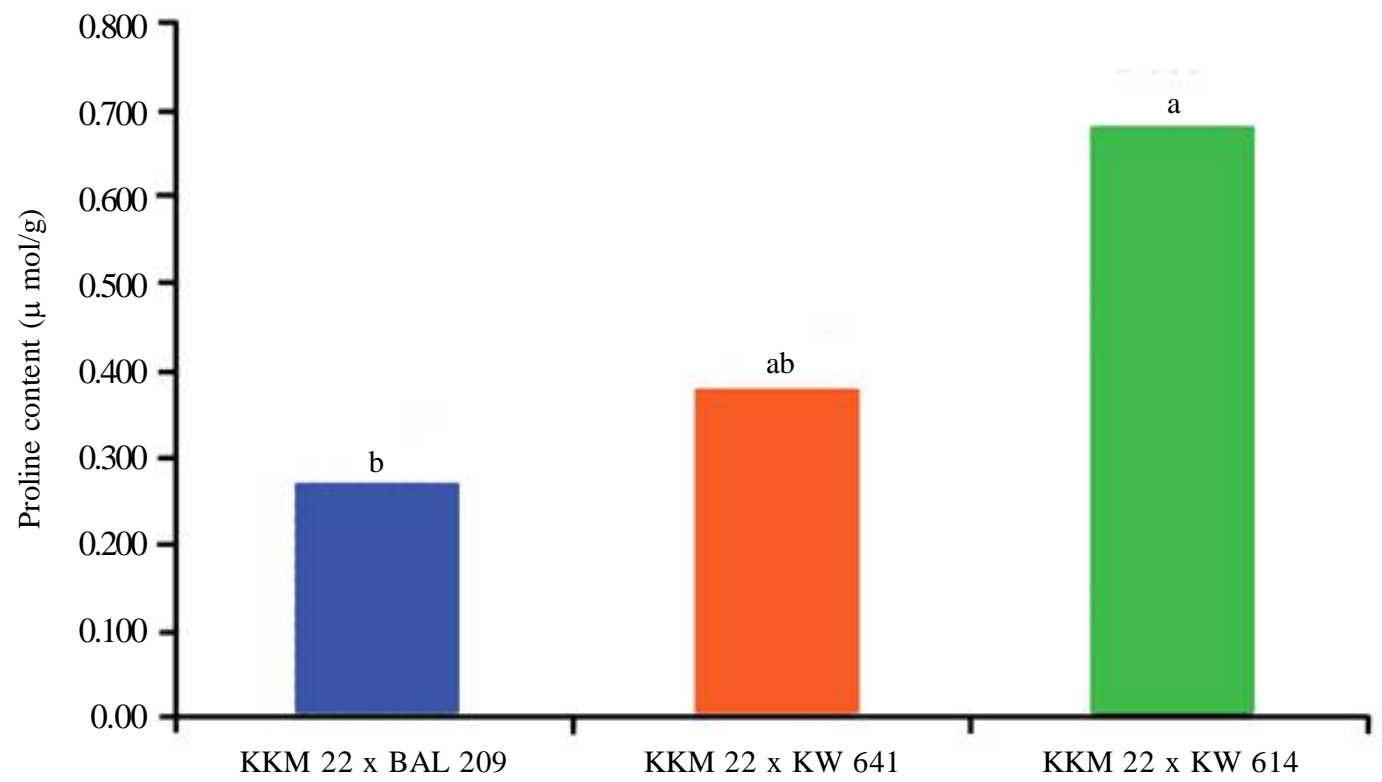

Figura 4. Root proline content of these cocoa seedling populations (bars that followed by same letter are not significant based on duncan test with $\alpha=0.05$ )

\section{CONCLUSIONS}

The rootstock characters that play a role in their response to drought are stem diameter, rootcanopy ratio, root dry weight and root volume. seedlings from KKM $22 \times$ BAL 209 and KKM $22 \times$ KW 641 has a high value compared to seedlings of crossbreeding KKM 22 x KW 614 on that rootstock characters. Based on the resistance to drought stress, KKM 22 x KW 641 is quite tolerant to drought while the other two breeds are susceptible to drought. KKM 22 x BAL 209 and KKM 22 x KW 641 have low proline production capability under various conditions of water availability.

\section{ACKNOWLEDGEMENT}

The authors would like to thank the Director of Indonesian Coffee and Cocoa Research Institute for the facility and financial support for the research. Thanks also the authors say to Arik Ermawan and Dedi Anwar, A. Md. for his assistance in collecting research data.

\section{REFERENCES}

Adjaloo, M.K.; W. Oduro \& B.K. Banful (2012). Floral phenology of Upper Amazon cocoa trees : implications for reproduction and productivity of cocoa. International Scholarly Research Network Agronomy, 2012, 1-7.

Ajayi, A.T.; M.O. Adekola; B.H. Taiwo \& V.O. Azuh (2014). Character expression and differences in yield potential of ten genotypes of cowpea (Vigna unguiculata $\mathrm{L}$. Walp). International Journal of Plant Research, 4, 63-71.

Amos, T.T.; \& O.A. Thompson (2015). Climate change and the cocoa production in the tropical rain forest ecological zone of Ondo State, Nigeria. Journal of Environment and Earth Science, 5, 36-42.

Amrhein, N.; K. Apel; S. Baginsky; N. Buchmann; M. Geisler; F. Keller; C. Körnrt; E. Martinoia; L. Merbold; C. Müller; M. Paschke \& B. Schimid (2013). Plant Response to Stress. ETH Library. Zürich. 
Ayegboyin, K.O. \& E. A. Akinrinde (2016). Effect of water deficit imposed during the early developmental phase on photosynthesis of cocoa (Theobroma cacao L.). Agricultural Sciences, 7, 11-19.

Backlund, P.; J. Anthony \& S. David (2018). The Effects of Climate Change on Agriculture, Land Resources, Water Resources, and Biodiversity in the United States. United States Climate Change Science Program. United States of America.

Bates, L.S.; R.P. Waldren \& I.D. Teare (1973). Rapid determination of free proline for water-stress studies. Plant and Soil, 39, 205-207.

Beets, P.N.; S.H. Pearce; G.R. Oliver \& P.W. Clinton (2017). Root/shoot ratios for deriving below-ground biomass of Pinus Radiata stands. New Zealand Journal of Forestry Science, 37, 267-288.

Comas, L.H.; S.R. Becker; V.M.V. Cruz; P.F. Byrne \& D.A. Dierig (2013). Root traits contributing to plant productivity under drought. Frontiers in Plant Science, 4, 1-16.

Jones, H.G. (2012). Commentary how do rootstocks control shoot water relations? New Phytologist, 194, 301- 303.

Kramer, P.J. \& J.S. Boyer (1995). Water Relations of Plants and Soils. Academic Press. California.

Lum, M.S.; M.M. Hanafi \& A.S.N. Akmar (2014). Effect of drought stress on growth, proline, and antioxidant enzyme activities of upland rice. Journal of Animal and Plant Sciences, 24, 1487-1493.

Medeiros, D.B.; E. Ciriaco; H. Rafael; B. Santos; C.M. Pacheco; S. Musser; R. Jurema \& M. Custôdio (2012). Physiological and biochemical responses to drought stress in Barbados Cherry. Brazilian Society of Plant Physiology, 24, 181-192.

Nelson, V.; J. Morton; T. Chancellor; P. Burt \& B. Pound (2010). Climate Change, Agricultural Adaptation and Fairtrade Identifying the Challanges and Opportunities. Natural Resources Institute University of Greenwich. UK.
Ostonen, I.; Ü. Püttsepp; C. Biel; O. Alberton; M.R. Bakker; K. Lõhmus; D. Metcalfe; A.F.M. Olsthoorn; A. Pronk; E. Vanguelova; M. Weih \& I. Brunner (2007). All aspects of plant biology : specific root lenghth as an indicator of environmental change. Plant Biosystem, 141, 426-442.

Paez-garcia, A.; C.M. Motes; R. Chen; E.B. Blancafor; M.J. Monteros; T. Samuel; R. Noble \& S.N. Parkway (2015). Root traits and phenotyping strategies for plant improvement. Plants, 4, 334-355.

Prawoto, A.A.; A. Salam \& Slameto (2003). Respons semaian beberapa klon kakao terhadap cekaman kekeringan. Pelita Perkebunan, 19, 55-56.

Pusat Penelitian Kopi dan Kakao Indonesia (2015). KAKAO : Sejarah, Botani, Proses Produksi, Pengolahan, dan Perdagangan. Gadjah Mada University Press. Yogyakarta.

Savitri, E.S. (2010). Pengujian in vitro beberapa varietas kedelai (Glycine max L. Merr) pada media padat dan cair. El-Hayah, 1,9-13.

Shirani Rad, A.H. \& A. Abbasian (2011). Evaluation of drought tolerance in winter rapeseed cultivar based on tolerance and sensitivity indices. Pemdirbystë, 98, 41-48.

Siddique, K.H.M.; Y.L. Chen \& Z. Rengel (2015). Efficient root system for abiotic stress tolerance in crops. Procedia Environmental Sciences, 29, 295-269.

Solomon, S.; G. Plattner; R. Knutti \& P. Friedlingstein (2009). Irreversible climate change due to carbon dioxide emissions. Proceedings of National Academy of Sciences of the United States of America, 1704-1709.

Sudarmadji, S.; M. Rusim \& S. Hadi (2007). Variasi genetik, heritabilitas, dan korelasi genotipik sifat-sifat penting tanaman wijen (Sesamum indicum L.). Jurnal Litri, 13, 88-92.

Susilo, A.W.; I.A. Sari; E. Sulistyowati; F. Nur'aini \& N.A. Febrianto (2015). Perakitan bahan tanam unggul kakao (Theobroma 
cacao L.) tahan hama penggerek buah kakao (Conopomorpha cramerella Snell.), penyakit pembuluh payu (Oncobasidium theobromae) dan penyakit busuk buah (Pytophthora palmivora). Laporan Penelitian Rutin. Pusat Penelitian Kopi dan Kakao Indonesia.
Vadez, V. (2014). Root hydraulics : the forgotten side of roots in drought adaptation. Field Crops Research, 165, 15-24.

Visscher, P.M.; W.G. Hill \& N.R. Wray (2008). Heritability in the genomics eraconcepts and misconceptions. Nature Reviews Genetics, 9, 255-266.

$$
* * 0 * *
$$

